
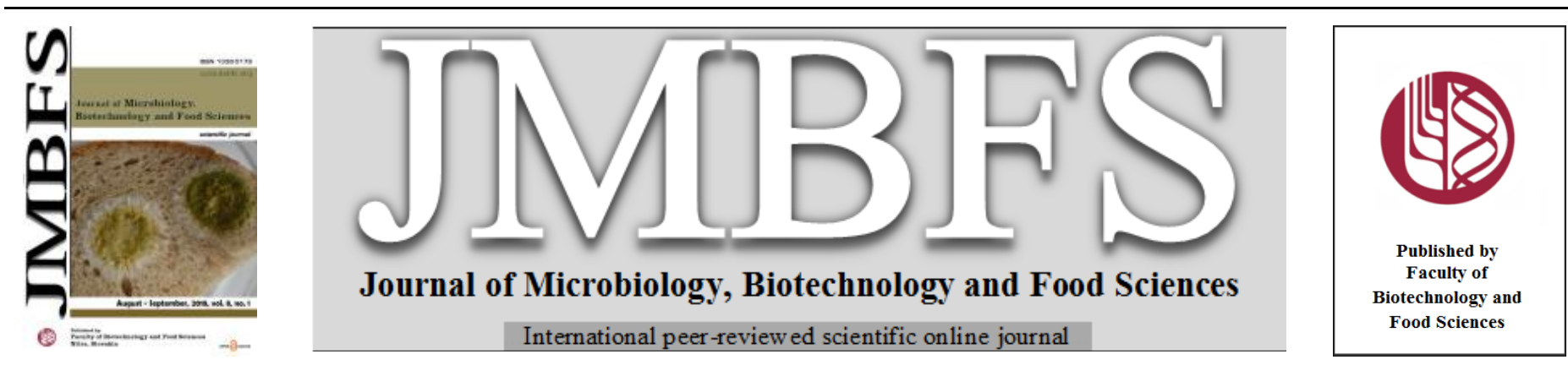

\title{
PURIFICATION OF AN EXO-INULINASE FROM BACILLUS SP. SG7
}

\author{
Viara Ivanova*1, Simeon Gavrailov ${ }^{1}$, Veronica Pashkoulova ${ }^{2}$ \\ Address(es): Viara Ivanova, $\mathrm{PhD}$ \\ ${ }^{\prime}$ University of Food Technologies - Plovdiv, Department of Microbiology, 26 Maritsa blvd, 4002 Plovdiv, Bulgaria; \\ ${ }^{2}$ Plovdiv University "Paisii Hilendarski”, 24 Tsar Assen str., 4002 Plovdiv, Bulgaria.
}

*Corresponding author: vn.ivanova@abv.bg

doi: 10.15414/jmbfs.2018.8.1.685-691

ARTICLE INFO

Received 30. 5. 2018

Revised 6. 6. 2018

Accepted 2. 7. 2018

Published 1. 8. 2018

Regular article

OPEN $\partial_{\text {ACCESS }}$

\begin{abstract}
An exo-inulinase from strain Bacillus sp. SG7 was isolated and purified. A two-phase system PEG/Dextran, size-exclusion chromatography and ion-exchange chromatography were used in the purification process. The enzyme was purified to homogeneity with specific inulinase activity $18.47 \mathrm{U} / \mathrm{mg}$ protein and specific invertase activity $196.5 \mathrm{U} / \mathrm{mg}$ protein, purification fold of 10.44 and $27.4 \%$ yield. The molecular mass of the purified enzyme was estimated to be $56000 \mathrm{Da}$. Strong inhibitors of enzyme activity are $\mathrm{Pb}$, $\mathrm{Hg}, \mathrm{Zn}$ and $\mathrm{Cu}$ ions with inhibition levels rising up to $55 \%$ for $\mathrm{Cu}$ and $95 \%$ for $\mathrm{Pb}$. SDS totally inhibited the purified inulinase. The kinetic constants $\mathrm{Km}$ and Vmax for inulin as substrate were determined to be $1.0 \mathrm{mg} / \mathrm{mL}$ and $6.25 \mathrm{mg} / \mathrm{mL}$.h, respectively. The $\mathrm{pH}$ optimum is at $\mathrm{pH} 7.0$ and the enzyme is stable between $\mathrm{pH} 6.0$ and $\mathrm{pH} 7.5$, while retaining $100 \%$ of its initial activity between $\mathrm{pH} 6.5$ and $\mathrm{pH}$ 7.0. The temperature optimum for the purified inulinase from strain Bacillus sp. SG7 was at $60^{\circ} \mathrm{C}$. In the presence of inulin the purified inulinase sustains its activity at $100 \%$ for 55 minutes at $65^{\circ} \mathrm{C}$. After the $70^{\text {th }}$ minute the residual activity is $63 \%$ of the initial. The enzyme showed capacity to hydrolyse sucrose, raffinose and inulin from which it liberated only fructose units showing, therefore, an exo-action mechanism. The inulins from chicory (Cichorium intibus), from dahlia (Dahlia pinnata) and Jerusalem artichoke (Helianthus tuberosus) roots were hydrolysed by the purified enzyme.
\end{abstract}

Keywords: inulinase, Bacillus, thermophile, purification, characterization

\section{INTRODUCTION}

Inulin belongs to a class of carbohydrates known as fructans - polymers composed mainly of fructose units, and typically with a terminal glucose molecule. Fructose residues are linked together by $\beta-(2,1)$ or $\beta-(2,6)$ glycosidic bonds (Gupta and Kaur, 1997; Rocha et al., 2006). Inulin type fructans are linear compounds in which fructose residues are mostly linked by $\beta$ $(2,1)$ linkages (Rocha et al., 2006). Inulin is naturally synthesized by over 45 000 plants. It acts as a storage carbohydrate in garlic, asparagus roots, topinambour, dahlia, chicory rhizomes and roots, as well as in dandelion, burdock and the European goldenrod. Inulin quantities in fresh mass from these sources range from $10 \%$ to $20 \%$ (Rocha et al., 2006; Kango and Jain, 2011). Fructans are typical prebiotics and have a proven stimulating effect on bifidobacteria in animals and humans. These sugars have a low caloric value and act as dietary fiber because the digestive enzymes in the upper part of the gastrointestinal tract are unable to hydrolyze $\beta$-fructosyl bonds. Fructans are selectively metabolized in the large intestine by bifidobacteria and lactobacilli, which suppress the growth of pathogenic species such as Escherichia coli, Clostridium sp. and Salmonella sp. Bifidobacteria and lactobacilli produce shortchained fatty acids and lactic acid from inulin, which in turn leads to a higher Calcium and Magnesium assimilation, vitamin B synthesis, lower levels of serum cholesterol, and large intestine cancer prevention. It is believed that fructooligosaccharides can inhibit tumor growth (Gao et al., 2009).

Inulin can be hydrolyzed at $\mathrm{pH} 1.0-2.0$ and temperature of $80-100^{\circ} \mathrm{C}$, but low $\mathrm{pH}$ levels cause fructose degradation and can also lead to the formation of difructose anhydrides. Chemical hydrolysis of inulin with organic or mineral acids or through heterogeneous catalysis with solid acid catalysts, such as acid cation exchange resins or oxidized activated carbon, is disadvantageous because it results in unwanted side products and coloring compounds. This then requires special treatment, thus rendering the process inefficient. These disadvantages can be overcome if a specialized enzyme method is applied. Pure fructose syrup from inulin can be derived through treatment with microbial inulinases.

Inulinases are fructofuranosyl hydrolases produced by a wide range of microorganisms (Singh and Gill, 2006). These enzymes also possess an invertase activity (hydrolysis of saccharose). During the past few decades a wide variety of microorganisms such as bacteria (Clostridium spp., Xanthomonas spp.,
Bifidobacterium spp., Geobacillus spp., Bacillus spp., Thermotoga spp., Pseudomonas spp.), yeast (Kluyveromyces spp.) and ascomycetous fungi (Penicillium spp., Fusarium spp., Aspergillus spp.) has been used for inulinase production (Pandey et al., 1999; Kango and Jain, 2011; Neagu (Bonciu) and Bahrim, 2011). Amongst the most commonly used genera are Aspergillus, Kluyveromyces (Pandey et al., 1999) along with Pseudomonas, Xanthomonas, Penicillium, Chrysosporium (Kango and Jain, 2011; Neagu (Bonciu) and Bahrim, 2011) and Bacillus (Zherebtsov et al., 2002; Kim et al., 2004).

Bacterial inulinases are essential to the industry as they are inductive, extracellular (Jain et al., 2012) and thermostable (Ettalibi and Baratti, 2001). Due to bacteria's ability to withstand extremely high temperatures, there have been attempts to isolate such strains which can produce high quantities of thermostable inulinases. Successful isolation of number of Arthrobacter ureafaciens mutants that produce a thermostable inulinase was reported. According to Allais et al., (1986), the inulinases are secreted into the growth medium.

It has been proven that $\beta$-fructofuranosidase, purified from Arthrobacter, has an exo-enzyme type of action at optimal $\mathrm{pH}$ value of 6.0 and optimal temperature of $50^{\circ} \mathrm{C}$ (Elyachioui et al., 1992). Takahashi et al. (1985) purified to homogeneity an exo-inulinase with molecular mass of $83 \mathrm{kDa}$ from Streptococcus salivarius.

Bacteria from genus Bacillus are also active producers of extracellular inulinases (Uzunova et al., 2002). Bacillus subtilis 430A, isolated from the rhizospehere of Vernonia herbacea, produces an extracellular inulinase (Vullo et al., 1991). Meenakshi et al., (2013) have isolated an extracellular inulinase producer that has been identified as Bacillus cereus MU-31, which has the ability to produce large quantities of the enzyme - $3783 \mathrm{U} / \mathrm{mL}$ after 36 hours of cultivation. Achromobacter sp. has been reported to have high enzymatic activity of $333 \mathrm{U} / \mathrm{L}$ after $22 \mathrm{~h}$ of cultivation (Jenny et al., 2012). Another species of the Bacillus genus - Bacillus safensis, can produce an endoinulinase with maximum inulinase activity of $12.56 \mathrm{U} / \mathrm{mL}$ (Singh et al., 2013).

Allais et al. (1987a) isolated a thermophillic strain from genus Bacillus that produces an inulin inductive inulinase. The partially purified inulinase from Bacillus subtilis shows higher specificity towards inulin ( $\mathrm{Km} 8 \mathrm{mM})$ compared to saccharose $(\mathrm{Km} 56 \mathrm{mM})$. The thermophillic soil isolate Bacillus stearothermophilus KP1289, which develops at temperatures ranging from 41 to $69^{\circ} \mathrm{C}$, produces an inulin inductive extracellular inulinase with molecular mass of 
$54 \mathrm{kDa}$ and $\mathrm{pI}$ of 5.0 (Kato et al., 1999). Zherebtsov et al. (2002) studied the synthesis of extracellular inulinase from Bacillus polymyxa 29, Bacillus polymyxa 722, and Bacillus subtilis 68. Maximum enzyme production was observed after 72 hours of incubation at temperatures between 33 and $35^{\circ} \mathrm{C}$ and $\mathrm{pH} 7.0$. Gao et al., (2009) used a medium containing only inulin as a carbon source and isolated a new thermophillic inulinase producing strain with optimal development temperature of $60^{\circ} \mathrm{C}$. Following a $16 \mathrm{~S}$ rDNA analysis the strain was identified as Bacillus smithii. Using only inulin as a carbon source, Allais et al., (1987b) have successfully isolated 5 thermotolerant and 4 thermophillic species from genus Bacillus, whilst Drent et al., (1991) isolated thermophills from genus Clostridium. Based on their ability to secrete a large amount of succinate during fermentation, the latter have been suggested to be named Clostridium thermosuccinogenes.

The gene coding one of the most thermostable bacterial inulinases, which can sustain $85 \%$ of its original activity for up to 5 hours at $80^{\circ} \mathrm{C}$ and $\mathrm{pH} 7.0$, has been cloned from Thermotoga maritima (Liebl et al., 1998). Thermotoga maritima is a strictly anaerobic heterotroph with optimal growth at $90^{\circ} \mathrm{C}$.

Industrial fructose and fructooligosaccharide production happens at approximately $60^{\circ} \mathrm{C}$ (Vandamme and Derycke, 1983; Vijayaraghavan et al., 2009; Chi et al., 2011). For the most part, inulinase activity drops after a few hours at said temperature and addition of enzyme increases the cost of the end product. Therefore the isolation of thermostable inulinases is essential, as it would solve this problem. Inulinases from various microbial sources have been isolated and characterized. Unfortunately, only a small part of which have a temperature optimum of $60^{\circ} \mathrm{C}$ and a considerable thermal stability (Ettalibi and Baratti, 1987; Ettalibi and Baratti, 2001; Kwon et al., 2003; Sharma and Gill, 2007; Neagu (Bonciu) and Bahrim, 2011; Shen et al., 2015). It is for these reasons that the matter of thermostable inulinases, produced by thermophillic microorganisms remains relevant.

\section{MATERIAL AND METHODS}

\section{Bacterial strain isolation}

The strain of Bacillus sp. SG7 was isolated from thermal water samples from the region of Velingrad (Kostandovo, Bulgaria) with temperature $58^{\circ} \mathrm{C}$ and $\mathrm{pH} 7.5$ Five milliliters from the samples were mixed with $5 \mathrm{~mL}$ isolation medium and incubated at $37^{\circ} \mathrm{C}$ and $50^{\circ} \mathrm{C}$ for $48 \mathrm{~h}$ for enrichment. After that suspensions were heated at $80^{\circ} \mathrm{C}$ for $10 \mathrm{~min}$ because the methods for isolation of Bacillus strains are based on the resistance of their spores towards elevated temperatures (Sneath, 1986). After chilling, $5 \mathrm{~mL}$ from these suspensions were mixed again with $5 \mathrm{~mL}$ isolation medium and cultivated for $48 \mathrm{~h}$ at $37^{\circ} \mathrm{C}$ and $50^{\circ} \mathrm{C}$. Then the samples were serially diluted prior to plating $30 \mu \mathrm{L}$ on meat agar $(1.5 \%(\mathrm{w} / \mathrm{v})$, Oxoid) containing inulin for isolation of single colonies. Plates were incubated at $37^{\circ} \mathrm{C}$ and $50^{\circ} \mathrm{C}$ for 3 days. Pure colonies were obtained by repetitive dilution streaking on peptone-yeast extract agar with additional inulin $(0.2 \%, \mathrm{w} / \mathrm{v})$ as carbon source which helped in the selection of colonies having inulinase enzyme activity. The Petri dishes were incubated at $37^{\circ} \mathrm{C}$ and $50^{\circ} \mathrm{C}$ for 3 days. The active cultures were transferred several times on the same agar medium, and then individual colonies were isolated. Ten strains of Bacillus were thus isolated. The strains were screened for exo-inulinase production. The strain designated as Bacillus sp. SG7 achieved the highest enzyme activity, and it was selected for further studies and stored at $4^{\circ} \mathrm{C}$ (Gavrailov and Ivanova, 2014).

\section{Fermentation medium}

The medium used for strain isolation, maintenance and enzyme production had the following composition $(\mathrm{g} / \mathrm{L})$ : peptone (Oxoid, Basingstoke, $\mathrm{UK})-2.0$; yeast extract (Oxoid) - 2.0; $\mathrm{K}_{2} \mathrm{HPO}_{4}-0.4 ; \mathrm{MgSO}_{4}-0.08$ and inulin (from Dahlia tubers, Fluka, Buchs, Switzerland) - 2.0. Inulin was sterilized separately for 20 min at $110^{\circ} \mathrm{C}$ and added to the medium before inoculation. Sterile sodium carbonate was used to adjust the medium to $\mathrm{pH}$ 8.0-8.5 after autoclaving. Erlenmeyer flasks (300-mL volume) were charged with $50 \mathrm{~mL}$ of the medium, inoculated (2\%) with a culture, previously incubated for $18 \mathrm{~h}$, and incubated at $37^{\circ} \mathrm{C}-70^{\circ} \mathrm{C}$ in water-bath (Julabo SW22) shaker, for $36 \mathrm{~h}$, at $200 \mathrm{rpm}$.

\section{Inulinase assay}

The culture medium was centrifuged at $4000 \mathrm{rpm}$ for $15 \mathrm{~min}$ and the supernatant was used as the inulinase source. Inulinase activity was measured by determination of the reducing sugars released from substrate inulin by DNSmethod (Miller, 1959). The reaction mixture contained $100 \mu \mathrm{L}$ substrate inulin (from Dahlia tubers, Fluka, Buchs, Switzerland; $20 \mathrm{~g} / \mathrm{L}$, phosphate buffer $\mathrm{pH}$ 7.0) and $100 \mu \mathrm{L}$ enzyme solution. After incubation at $60^{\circ} \mathrm{C}$ for 20 minutes the reaction was stopped by $200 \mu \mathrm{L}$ DNS-reagent. Reducing sugars were determined by calibration curve obtained using a standard solution of fructose (Scharlab S.L., Spain). One unit of inulinase activity was defined as the amount of enzyme that liberates one $\mu \mathrm{mol}$ of fructose per minute under the assay conditions.

\section{Invertase assa}

Invertase activity was determined under the conditions described above with saccharose (Scharlab S.L., Spain; $20 \mathrm{~g} / \mathrm{L}$ in phosphate buffer, $\mathrm{pH}$ 7.0) as substrate. A calibration curve was obtained using an equimolar standard solution of glucose and fructose. One unit of invertase activity was defined as the amount of enzyme that hydrolyzes $1 \mu \mathrm{mol}$ of saccharose per minute under the assay conditions.

\section{Determination of protein, cell growth}

Total protein content in enzyme solution was measured by the Bradford method (Bradford, 1976), using bovine serum albumin as standard. The culture growth was determined by the absorbance at $650 \mathrm{~nm}$.

\section{Enzyme purification}

A two-phase separation method was used for the purification of inulinase from strain Bacillus sp. SG7 (Ivanova et al., 1993). $100 \mathrm{~mL}$ of the supernatant were mixed with a 50\% PEG 6000 solution and a 30\% dextran 500 solution respectively, thus obtaining solutions with $15 \%$ and $6 \%$ final concentration. The dextran fraction was used in a size-exclusion chromatography column (2.6 x 75 cm, LKB system) with Sephadex G-100 (Pharmacia Fine Chemicals), balanced with $0.025 \mathrm{M}$ Tris- $\mathrm{HCl}$ buffer with $\mathrm{pH}$ 7.3. Samples of $4 \mathrm{~mL}$ each were collected at $15 \mathrm{~mL} / \mathrm{h}$ flow rate. The samples were analysed for protein by the Bradford method. The fractions with inulinase and invertase activities were collected and concentrated with ultrafiltration system Amicon (Amicon Corp., USA, pore size $10000 \mathrm{Da}$ and pressure $0.5 \mathrm{MPa}$ ) and were afterwards subjected to ion-exchange chromatography through a column containing CM Sepharose CL-6B (Pharmacia Fine Chemicals, $1.6 \times 40 \mathrm{~cm}$ ), balanced with $0.05 \mathrm{M}$ sodium-acetate buffer with $\mathrm{pH}$ 5.0. Fractions of $1 \mathrm{~mL}$ each were collected at flow rate $40 \mathrm{~mL} / \mathrm{h}$. A $0 \rightarrow 2.0 \mathrm{M}$ $\mathrm{NaCl}$ gradient in sodium acetate buffer, $\mathrm{pH} 5.0$, was applied. The inulinase and invertase fractions were collected, subjected to dialysis in $0.025 \mathrm{M}$ Tris- $\mathrm{HCl}$ buffer with $\mathrm{pH} 7.3$ at $4^{\circ} \mathrm{C}$ and concentrated.

\section{Enzyme homogeneity and molecular mass determination}

SDS-PAGE electrophoresis was used. For the molecular mass determination of the separated protein fractions, molecular standards from Bio-Rad (Bio-Rad, Bio-Rad Laboratories, USA) with 7 proteins with respective masses of 200, 97, 69, 45, 30, 21, $14 \mathrm{kDa}$ were applied. Polyacrylamide gel electrophoresis at denaturizing conditions was conducted according to the Laemmli method (Laemmli, 1970), using a Mini-PROTEANII (Bio-Rad Laboratories, USA). A $14 \%$ separating gel and $6 \%$ concentrating gel with $1.5 \mathrm{~mm}$ width were used. The electrophoretical separation was performed at constant voltage of $120 \mathrm{~V}$, at room temperature for 100 minutes. After electrophoresis the gels were either silver stained (Blum et al., 1987) or stained with a Coomassie Brilliant Blue R-250 solution.

\section{Enzyme characterization}

\section{pH and temperature optima and stability}

The effect of $\mathrm{pH}$ on the purified inulinase was investigated by measuring the enzyme activity at $60^{\circ} \mathrm{C}$ over the $\mathrm{pH}$ range 3.5 to $6.5(0.1 \mathrm{M}$ acetate buffer $), 6.8$ 7.7 (0.1 M phosphate buffer) and 8 to 9.0 (0.1 M Tris-HCl buffer).

For the $\mathrm{pH}$ stability determination, aliquots of $0.5 \mathrm{~mL}$ of enzyme $(1.0 \mathrm{U} / \mathrm{mL})$ plus $0.5 \mathrm{~mL}$ of the same buffer in the mentioned $\mathrm{pH}$ range were maintained at $20^{\circ} \mathrm{C}$ for $1 \mathrm{~h}$ and the residual activity was estimated. The activity of a control assay with no $\mathrm{pH}$ treatment is regarded as the maximum activity of $100 \%$.

The optimum temperature was determined by measuring the enzyme activity in $0.1 \mathrm{M}$ phosphate buffer, $\mathrm{pH} 7.0$ in the temperature range from $40^{\circ} \mathrm{C}$ to $70^{\circ} \mathrm{C}$.

For the thermal stability determination of the inulinase, a reaction medium composed of $0.5 \mathrm{~mL}$ of enzyme solution $(1.0 \mathrm{U} / \mathrm{mL})$ and $0.5 \mathrm{~mL}$ of $0.1 \mathrm{M}$ phosphate buffer with a $\mathrm{pH}$ value of 7.0, was maintained from 5 to $60 \mathrm{~min}$ at $65^{\circ} \mathrm{C}$ in the presence of $1 \%$ inulin or without inulin and the residual activity was measured as described in the enzyme assay.

\section{Determination of kinetic constants}

$\mathrm{Km}$ and Vmax for an inulin substrate were determined at the optimal temperature for enzyme action. The concentration of the inulin substrate from dahlia (Dahlia tubers, Fluka, Buchs, Switzerland) was between 2.5 and $10.0 \mathrm{~g} / \mathrm{L}$; the enzyme concentration was $0.9 \mu \mathrm{g} / \mathrm{mL}$. The constants were calculated using the Lineweaver-Burk plot (Dixon and Webb, 1979).

\section{Effect of metal ions and reagents}

The effects of the following metal ions and reagents on the inulinase activity of the purified enzyme were studied: $\mathrm{Mn}^{2+}$ (as $\left.\mathrm{MnSO}_{4} \cdot \mathrm{H}_{2} \mathrm{O}\right), \mathrm{Fe}^{2+}\left(\mathrm{FeCl}_{2}\right), \mathrm{Fe}^{3+}$ 
$\left(\mathrm{FeCl}_{3}\right), \mathrm{Pb}^{2+}\left(\mathrm{Pb}\left(\mathrm{CH}_{3} \mathrm{COO}\right)_{2} .3 \mathrm{H}_{2} \mathrm{O}\right), \mathrm{Co}^{2+}\left(\mathrm{Co}\left(\mathrm{NO}_{3}\right)_{2}\right), \mathrm{Mg}^{2+}\left(\mathrm{MgCl}_{2} .7 \mathrm{H}_{2} \mathrm{O}\right), \mathrm{Hg}^{2+}$ $\left(\mathrm{HgCl}_{2}\right), \mathrm{K}^{+}(\mathrm{KCl}), \mathrm{Ag}^{+}\left(\mathrm{AgNO}_{3}\right), \mathrm{Ca}^{2+}\left(\mathrm{CaCl}_{2}\right), \mathrm{Na}^{+}(\mathrm{NaCl}), \mathrm{Na}_{2} \mathrm{EDTA}$, SDS and 2-Mercaptoethanol (all in concentration of $1.0 \mathrm{mM}$ ). The enzyme was incubated in the presence of the particular salt at $25^{\circ} \mathrm{C}$ for 60 minutes. The residual activity was determined afterwards. The activity of a control assay with no added ions was regarded as the maximum activity of $100 \%$.

\section{Inulinase action pattern}

Aliquots of $0.5 \mathrm{~mL}$ of the purified enzyme $(1.0 \mathrm{U} / \mathrm{mL})$ were incubated, separately in $2.0 \mathrm{~mL}$ of raffinose (Sigma-Aldrich, USA), sucrose (Scharlab S.L., Spain), melezitose (Sigma-Aldrich, USA) and inulin (Jerusalem artichoke, SigmaAldrich, USA) solutions, in a final concentration of $1.0 \%$ in $0.1 \mathrm{M}$ phosphate buffer, $\mathrm{pH} 7.0$, at $60^{\circ} \mathrm{C}$. The liberation of fructose from raffinose and inulin was determined by the DNS-method. The values obtained for the hydrolysis of raffinose reaction were divided by 2 , because to each molecule of liberated fructose, corresponds 1 reducing unit of melibiose. The profile of the enzyme reaction was visualized by thin layer chromatography (TLC).

\section{Hydrolysis of inulin from different sources}

For the hydrolysis studies of inulin from different origins, the reaction system was composed by $0.5 \mathrm{~mL}(4.0 \mathrm{U} / \mathrm{mL})$ of purified enzyme, $5 \mathrm{~mL}$ of dahlia (Dahlia pinnata), chicory (Cichorium intibus) or Jerusalem artichoke (Helianthus tuberosus) (Sigma-Aldrich, USA) 5.0\% inulin solutions in $0.05 \mathrm{M}$ phosphate buffer, $\mathrm{pH}$ 7.0.

\section{Thin-layer chromatography (TLC)}

TLC was performed on Silica gel 60 pre-coated plates (Merck, Darmstadt, Germany, $25 \times 25 \mathrm{~cm})$. A mixture of n-propyl alcohol/ethyl acetate/water (7:1:2, $\mathrm{v} / \mathrm{v} / \mathrm{v}$ ) was used as a developing solvent. Sugars were detected by spraying of the air-dried plates with staining reagent containing ethanol/acetic acid/sulfuric acid/anis aldehyde (9:0.1:0.5:0.5, v/v/v/v). Carbohydrates were revealed after heating for $10 \mathrm{~min}$ at $120^{\circ} \mathrm{C}$ and were visualized as dark green spots. Fructose, glucose, raffinose, melezitose, inulin, saccharose in concentration $2.5 \mathrm{mg} / \mathrm{mL}$ (Sigma, USA) were used as standards.

\section{RESULTS AND DISCUSSION}

\section{Purification}

Bacterial cells were separated by centrifuging at $4000 \mathrm{rpm}$ for $20 \mathrm{~min}$ and the clear supernatant was used in the next purification steps. The results from the two-phase separation in system of PEG 6000 and dextran 500 used for the purification of an inulinase from strain Bacillus sp. SG7 are shown on Table 1. The major part of the inulinase was retained in the dextran fraction. Only $8 \%$ of the inulinase were retained in the PEG fraction, with $90 \%$ remaining in the dextran fraction. The purification fold at this stage was 7.22, the specific activity increased from $1.77 \mathrm{U} / \mathrm{mg}$ protein to $12.78 \mathrm{U} / \mathrm{mg}$ protein. The separation from other proteins through size-exclusion chromatography was not completely effective as a few lines were observed after an SDS-electrophoresis (Figure 1A) Because of this the active fractions were concentrated and subjected to ionexchange chromatography. Thus the inulinase was purified 10.44-fold with $24.7 \%$ yield and $18.47 \mathrm{U} / \mathrm{mg}$ specific inulinase activity. The homogeneity of the purified enzyme was tested with SDS-PAGE (Figure 1B). The inulinase-active fractions were combined and concentrated to protein content $1.7 \mathrm{mg} / \mathrm{mL}$.

These results are comparable to those of Martirosyan (2004), who purified over 50 fold an intracellular inulinase from Bacillus subtilis using ion-exchange and adsorption chromatography and size-exclusion chromatography. A specific enzyme activity of $42.7 \mathrm{U} / \mathrm{mg}$ was reached. Ma et al. (2016) purified a thermostable inulinase from Kluyveromyces cicerisporus through ion-exchange chromatography with $64 \%$ yield and purification fold 4.13 . The purified enzyme had a specific activity of $88.7 \mathrm{U} / \mathrm{mg}$.

Specific invertase activity of the enzyme from strain Bacillus sp. SG7 increased from $18.85 \mathrm{U} / \mathrm{mg}$ protein (supernatant) to $136.1 \mathrm{U} / \mathrm{mg}$ protein in the dextran fraction, to $153.8 \mathrm{U} / \mathrm{mg}$ protein after separation with size-exclusion chromatography on Sephadex G-100 and to $196.5 \mathrm{U} / \mathrm{mg}$ protein after ionexchange chromatography. According to Belamri et al. (1994) the inulin degrading enzymes are characterized by the S/I ratio, which is lower than 50 for inulinases and between 1600 and 2800 for invertases. It is evident from the results that the saccharose/inulin (S/I) ratio for the studied protein was 10.64 (after ion-exchange chromatography), thus proving that the enzyme from strain Bacillus sp. SG7 is inulinase.

Table 1 Purification of the inulinase from strain Bacillus sp. SG7

\begin{tabular}{lcccccc}
\hline Purification & $\begin{array}{c}\text { Volume } \\
(\mathbf{m L})\end{array}$ & $\begin{array}{c}\text { Total protein } \\
(\mathbf{m g})\end{array}$ & $\begin{array}{c}\text { Total inulinase } \\
\text { activity } \\
(\mathbf{U})\end{array}$ & $\begin{array}{c}\text { Specific inulinase } \\
\text { activity } \\
(\mathbf{U} / \mathbf{m g})\end{array}$ & $\begin{array}{c}\text { Yield } \\
(\boldsymbol{\%})\end{array}$ & $\begin{array}{c}\text { Purification } \\
\text { fold }\end{array}$ \\
\hline Supernatant & 200 & 260.0 & 460.0 & 1.77 & 100 & $(1.0)$ \\
PEG-fraction & 276 & 210.2 & 40.0 & - & - & - \\
Dextran fraction & 56 & 32.4 & 414.0 & 12.78 & 90.0 & 7.22 \\
Sephadex G-100 & 374 & 18.35 & 264.4 & 14.41 & 57.6 & 8.15 \\
CM Sepharose CL-6B & 106 & 6.16 & 113.8 & 18.47 & 24.7 & 10.44 \\
\hline
\end{tabular}

A

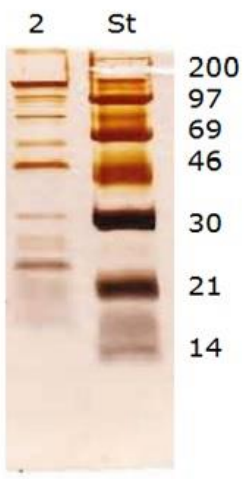

B

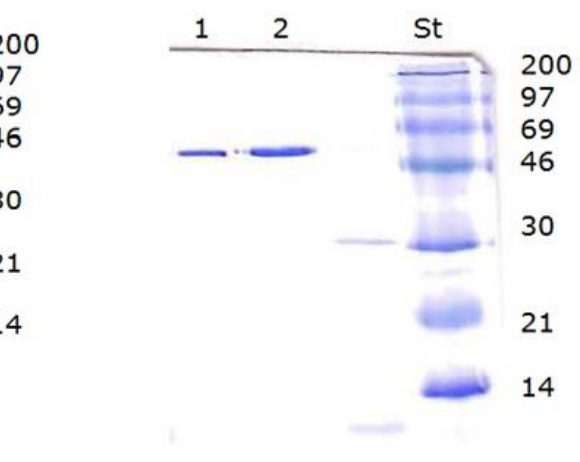

Figure 1 A: SDS-PAGE after size-exclusion chromatography, silver staining, 2 inulinase from Bacillus sp. SG7, St - molecular standards Bio-Rad. B: SDSPAGE after ion-exchange chromatography, staining with Coomassie Brilliant Blue R-250. 1, 2 - inulinase from strain Bacillus sp. SG7 (line 2 has a higher protein concentration); St- molecular standards Bio-Rad.

\section{Molecular mass determination}

The molecular mass of the enzyme has been determined based on the results from the two SDS-PAGE electrophoresis (Figure 1) and was calculated to be $56 \mathrm{kDa}$ through the Rf values of individual protein markers and the logarithm of their molecular mass.

The molecular mass of the inulinase from strain Bacillus sp. SG7 is similar to the molecular mass of other purified bacterial, yeast and fungi inulinases. It has been established that most microbial inulinases have a molecular mass over $50 \mathrm{kDa}$ (Chi et al., 2009) and under $60 \mathrm{kDa}$. For example, the molecular masses of 9 inulinases are between 49.8 and $59.1 \mathrm{kDa}$ (Liebl et al., 1998; Kwon et al., 2000; Tsujimoto et al., 2003; Kim et al., 2004; Nagem et al., 2004; Kobayashi et al., 2012; Gao et al., 2014; Liu et al., 2014). Kwon et al. (2003) found the molecular mass of exo-inulinase from Bacillus polymyxa to be $55522 \mathrm{Da}$.

Kang et al. (1998) characterized endoinulinases from Arthrobacter sp. and determined their molecular mass to be $75 \mathrm{kDa}$. Takahashi et al. (1985) purified to homogeneity an exo-inulinase with mass of $83 \mathrm{kDa}$ from Streptococcus salivarius. Shen et al. (2015) determined the molecular weight of an exoinulinase from Arthrobacter sp. HJ7 to be $95.1 \mathrm{kDa}$. Sharma and Gill (2007) purified an extracellular exo-inulinase from Streptomyces sp. with molecular mass of $45 \mathrm{kDa}$. The thermophillic soil species B. stearothermophilus KP1289, which grows at temperatures ranging from 41 to $69^{\circ} \mathrm{C}$, produces an inulin inductive extracellular inulinase with molecular mass and $\mathrm{pI}$ of $54 \mathrm{kDa}$ and 5.0, respectively (Kato et al., 1999).

The molecular masses of inulinases produced by bacteria are similar to those produced by yeast. Sheng $\boldsymbol{e t}$ al. (2008) purified and characterized an inulinase from Cryptococcus aureus and calculated its molecular mass to be $60 \mathrm{kDa}$. The inulinases obtained from Pichia guilliermondii have a molecular mass of $50 \mathrm{kDa}$ according to Gong et al. (2008) and $54 \mathrm{kDa}$ according to Chi et al. (2009). Inulinases with a molecular mass of $250 \mathrm{kDa}$ are produced by Kluyveromyces fragilis (Pandey et al., 1999).

The molecular mass of fungi produced inulinases varies between $50 \mathrm{kDa}$ and 300 $\mathrm{kDa}$ : Aspergillus ochraceus - $79 \mathrm{kDa}$ (Guimaraes et al., 2007), Penicillium spp. - $68 \mathrm{kDa}$ (Chi et al., 2009), Fusarium oxysporum - $300 \mathrm{kDa}$ (Pandey et al., 1999; Neagu (Bonciu) and Bahrim, 2011).

\section{pH-optimum and pH-stability}

The pH-optimum and the $\mathrm{pH}$-stability range of the purified inulinase are displayed in Figures 2 and 3. Optimum pH is at $\mathrm{pH} 7.0$ and the enzyme is stable 
between $\mathrm{pH} 6.0$ and $\mathrm{pH} 7.5$ as it sustains $100 \%$ of its activity in $\mathrm{pH} 6.5-7.0$, which slightly differentiates it from the partially purified enzyme with its $\mathrm{pH}-$ stability ranging from $\mathrm{pH} 5.5$ to $\mathrm{pH} 8.0$ (Gavrailov and Ivanova, 2014).

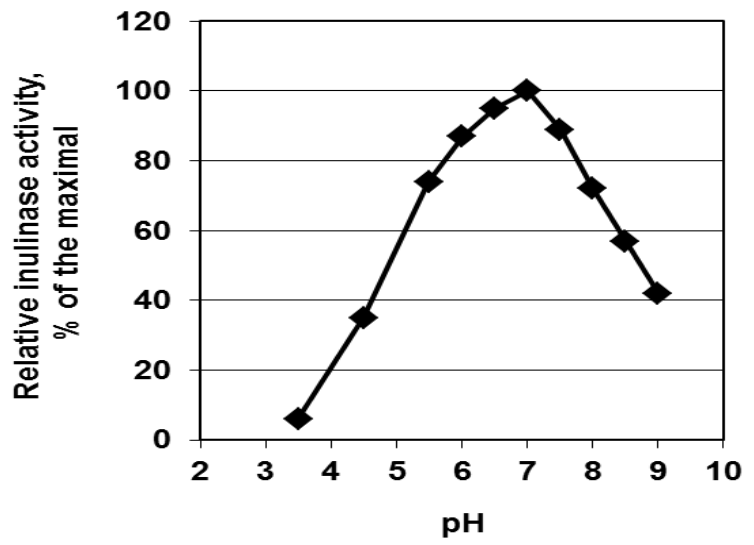

Figure 2 pH-Optimum of purified inulinase from strain Bacillus sp. SG7.

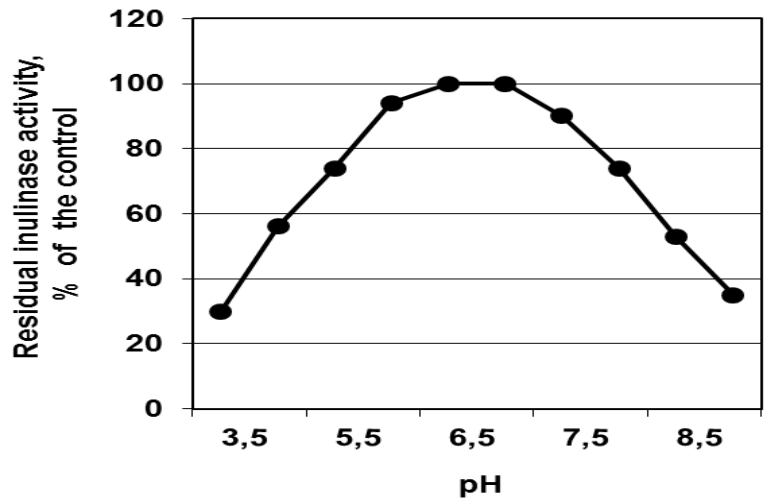

Figure 3 pH-Stability of purified inulinase from strain Bacillus sp. SG7.

Temperature optimum and temperature stability

Temperature optimum of the purified inulinase from strain Bacillus sp. SG7 has been determined to be at $60^{\circ} \mathrm{C}$ (Figure 4), same as the one of the partially purified inulinase (Gavrailov and Ivanova, 2014). At $70^{\circ} \mathrm{C}$ the enzyme shows $30 \%$ of its maximal activity as it is slightly more sensitive to this temperature, compared to its partially purified counterpart.

In the presence of inulin, the purified inulinase retained $100 \%$ of its activity for $55 \mathrm{~min}$ at $65^{\circ} \mathrm{C}$. After $70 \mathrm{~min}$ the remaining activity is $65 \%$ of the initial one (Figure 5). At temperature of $65^{\circ} \mathrm{C}$ its half-life is $72 \mathrm{~min}$ without inulin and 77 min in the presence of inulin.

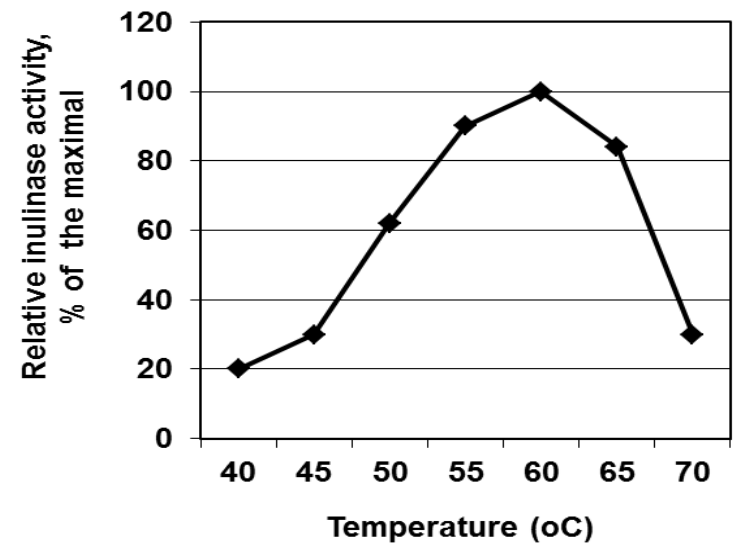

Figure 4 Temperature optimum of purified inulinase from strain Bacillus sp SG7.

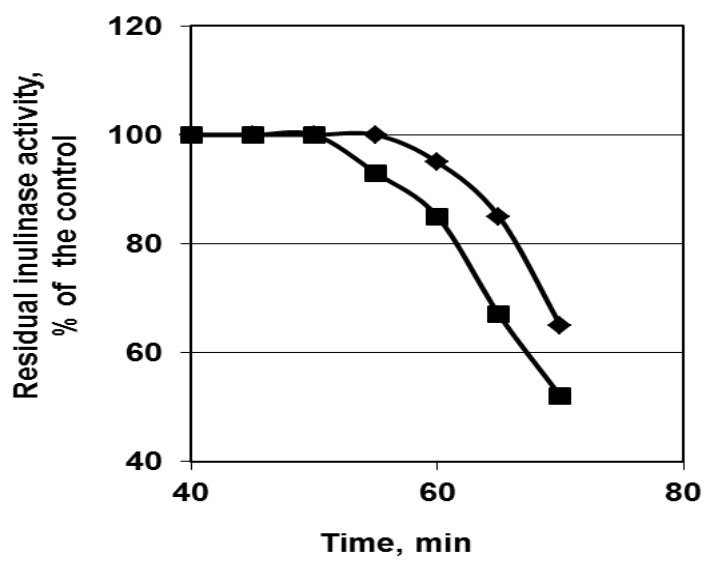

$\longrightarrow$ with inulin $\rightarrow$ without inulin

Figure 5 Thermal stability of purified inulinase from strain Bacillus sp. SG7 at $65^{\circ} \mathrm{C}$

Sharma and Gill (2007) purified an extracellular exo-inulinase from Streptomyces sp. with temperature optimum $70^{\circ} \mathrm{C}$ and $\mathrm{pH}$ optimum at $\mathrm{pH} 6.0$. Ma et al. (2016) successfully purified a thermostable inulinase from Kluyveromyces cicerisporus, the temperature and $\mathrm{pH}$ optimum for which are at $55^{\circ} \mathrm{C}$ and $\mathrm{pH} 4.5$, respectively. This inulinase can sustain $90 \%$ of its activity during one hour incubation at $50^{\circ} \mathrm{C}$. Shen et al. (2015) found that the exoinulinase from Arthrobacter sp. $\mathrm{HJ} 7$ has a temperature optimum range of 40$45^{\circ} \mathrm{C}$ and a $\mathrm{pH}$ optimum ranging between $\mathrm{pH} 5.0$ and 5.5. The enzyme is stable at $\mathrm{pH}$ 6.0-10.0 and can sustain up to $70 \%$ of its activity when incubated for $1 \mathrm{~h}$. At temperatures of $50^{\circ} \mathrm{C}$ and $60^{\circ} \mathrm{C}$ its half-life is $30 \mathrm{~min}$ and $10 \mathrm{~min}$, respectively. The thermostability of purified inulinase from strain Bacillus sp. SG7 is similar to that of the enzyme from Bacillus stearothermophilus (Belamri et al., 1994) or higher than that of several bacterial inulinases. For example, the exo-inulinase from Bacillus sp. LCB41 retains $70 \%$ of its initial activity after $10 \mathrm{~min}$ at $60^{\circ} \mathrm{C}$ (Allais et al., 1987a), the exo-inulinase from Arthrobacter sp. shows 50\% residual activity at $55^{\circ} \mathrm{C}$ after $30 \mathrm{~min}$ of incubation (Elyachioui et al., 1992). In comparison, the thermal stability of the enzyme from Bacillus sp. SG7 is significantly higher than the thermostabilities of inulinases from yeasts and fungi (Vandamme and Derycke, 1983)

Effects of metal ions and reagents

The effects of metals ions and EDTA on enzymatic activity in $1 \mathrm{mM}$ concentration were studied and the results are displayed in Table 2.

Table 2 Effects of metal ions and reagents

\begin{tabular}{ll}
\hline $\begin{array}{l}\text { Metal ions and reagents } \\
\text { Concentration 1.0 mM }\end{array}$ & Residual activity (\%) \\
\hline Standard probe containing & 100 \\
no ions or reagents & \\
$\mathrm{Al}^{3+}$ & 85 \\
$\mathrm{Mn}^{2+}$ & 77 \\
$\mathrm{Fe}^{2+}$ & 50 \\
$\mathrm{Fe}^{3+}$ & 71 \\
$\mathrm{~Pb}^{2+}$ & 5 \\
$\mathrm{Co}^{2+}$ & 75 \\
$\mathrm{Mg}^{2+}$ & 99 \\
$\mathrm{Hg}^{2+}$ & 26 \\
$\mathrm{Ca}^{2+}$ & 100 \\
$\mathrm{Cu}^{2+}$ & 45 \\
$\mathrm{Zn}^{2+}$ & 35 \\
$\mathrm{Na}^{+}$ & 97 \\
$\mathrm{~K}^{+}$ & 95 \\
$\mathrm{Ag}^{+}$ & 78 \\
$\mathrm{Na}_{2} \mathrm{EDTA}$ & 65 \\
$\mathrm{SDS}_{2-m e r c a p t o e t h a n o l}$ & 0 \\
\end{tabular}

No activation effect was observed. Magnesium, Calcium, Sodium, Potassium and 2-mercaptoethanol ions do not affect enzyme activity. $\mathrm{Al}^{3+}, \mathrm{Mn}^{2+}, \mathrm{Fe}^{3+}, \mathrm{Co}^{2+}, \mathrm{Ag}^{+}$ inhibit $15-30 \%$ of enzyme activity. $\mathrm{Fe}^{2+}$ and EDTA have a bigger impact on the enzyme and inhibit $35-50 \%$ of its activity. Other strong inhibitors are Lead ions (95\% inhibition), Zinc, Copper (55\% inhibition) and Mercury (74\% inhibition) SDS completely inhibits the purified inulinase. Lead ions affect sulfhydryl groups and their significant inhibitory properties could be linked to the fact that sulfhydryl groups are strongly connected to enzymatic activity, as previously discovered by Ettalibi and Baratti (1987) and Kochhar et al. (1997). 
Kwon et al. (2003) proved that the exo-inulinase from Bacillus polymyxa is completely inactivated when treated with $0.001 \mathrm{M} \mathrm{Ag}^{+}$and $\mathrm{Hg}^{+}$and concluded that the active site contains thiol groups. $\mathrm{Cu}{ }^{2+}, \mathrm{Zn}^{2+}$ and $\mathrm{Ni}^{2+}$ also inhibit said inulinase.

Shen et al. (2015) determined that the exo-inulinase produced by Arthrobacter sp. HJ7 is not affected by 1.0 and $10.0 \mathrm{mM} \mathrm{Zn}^{2+}$ and $\mathrm{Pb}^{2+}$ ions. Meanwhile, Ma et al. (2016) found that the exo-inulinase from Kluyveromyces cicerisporus is considerably inhibited by $\mathrm{Cu}^{2+}, \mathrm{Co}^{2+}, \mathrm{Fe}^{3+}$ and $\mathrm{Ag}^{+}$.

Many exo-inulinases can be inhibited by 1.0 and $5.0 \mathrm{mM}$ of $\mathrm{Zn}^{2+}$ and $\mathrm{Pb}^{2+}$ (Kwon et al., 2000; Kwon et al., 2003; Gill et al., 2006; Wang et al., 2011) with the exception of the exo-inulinases produced by Bacillus subtilis ssp. 168 (Wanker et al., 1995), Penicillium sp. TN-88 (Moriyama et al., 2002), InuAMN8 (Zhou et al., 2015), rInuAHJ7 (Shen et al., 2015).

\section{Determination of kinetic constants}

$\mathrm{Km}$ and Vmax for an inulin substrate were determined at the optimal temperature for enzyme action. The constants were calculated using the Lineweaver-Burk plot (Dixon and Webb, 1979) and the initial velocities of the enzyme reaction with different substrate concentrations. Said constants were calculated to be 1.0 $\mathrm{mg} / \mathrm{mL}(\mathrm{Km})$ and $6.25 \mathrm{mg} / \mathrm{mL} . \mathrm{h}$ (Vmax). The concentration of the inulin substrate from dahlia (Dahlia tubers, Fluka, Buchs, Switzerland) was between 2.5 and $10.0 \mathrm{~g} / \mathrm{L}$; the enzyme concentration was $0.9 \mu \mathrm{g} / \mathrm{mL}$.

In comparison, Trivedi et al. (2015) determined $\mathrm{Km}$ of an exo-inulinase from Aspergillus tubingensis $\mathrm{CR} 16$ to be $7.4 \mathrm{mg} / \mathrm{mL}$ and $\mathrm{Vmax}$ to be 52.0 $\mu \mathrm{mol} / \mathrm{mL}$.min. Sharma and Gill (2007) purified an extracellular exo-inulinase from Streptomyces sp. with inulin $\mathrm{Km}$ of $1.63 \mathrm{mM}$. Km and Vmax of a purified endoinulinase from Xanthomonas oryzae No.5 (Cho and Yun, 2002) are 16.7 $\mathrm{mg} / \mathrm{mL}$ and $12.1 \mathrm{mg} / \mathrm{mL} . \mathrm{h}$, respectively.

\section{Action of the inulinase on several substrates and substrate spectrum}

For determination of the substrate specificity of the obtained exo-inulinase, the enzyme reaction was carried out using 4 substrates (concentration $10 \mathrm{mg} / \mathrm{mL}$ ) inulin, sucrose, raffinose and melezitose (Table 3). Enzyme activity on substrates raffinose and melezitose was determined using the calibration curve with standard fructose solutions. The enzyme degrades inulin, sucrose, raffinose, whereas melezitose was not hydrolyzed.

Table 3 Substrate specificity

\begin{tabular}{lc} 
Substrate & Enzyme activity $(\mathbf{U} / \mathbf{m L})^{*}$ \\
\hline Inulin & 31.15 \\
Sucrose & 331.44 \\
Raffinose & 48.36
\end{tabular}

Melezitose

0

* Per mL of purified enzyme

The obtaining of fructose as the only hydrolysis product from inulin and its liberation from the sucrose and raffinose suggest an exo-action mechanism of the enzyme. This action pattern was confirmed also by the chromatogram on the Figure 6 . The hydrolysis products were analyzed by thin layer chromatography. Only fructose was the first produced product. Fructooligosaccharides were not detected after an initial $20 \mathrm{~min}$ of the process. The results testified to a typical mode of action of an exo-inulinase splitting fructose residues from fructose side of inulin molecule. Higher degree of hydrolysis of inulin from Jerusalem artichoke was achieved as compared to the hydrolysis of inulin from dahlia tubers and chicory (Figure 7).

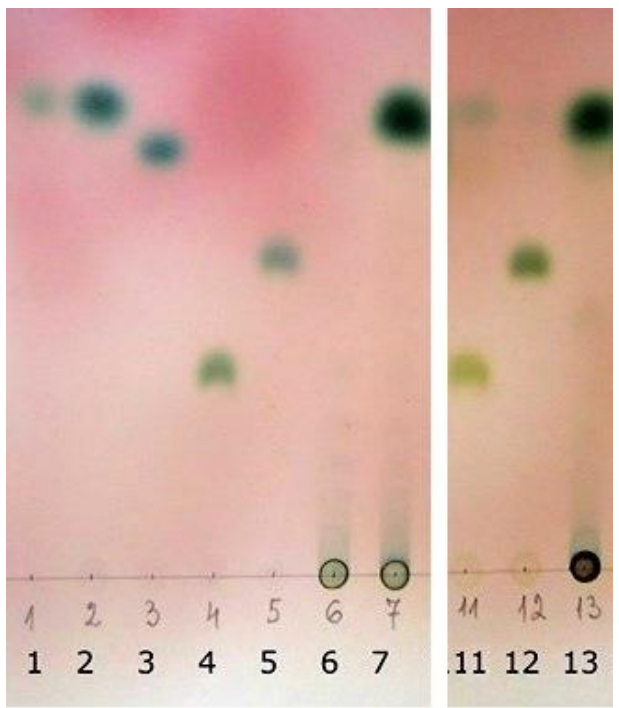

Figure 6 TLC of reaction products from hydrolysis of inulin, sucrose, raffinose and melezitose. Standards $2.5 \mathrm{mg} / \mathrm{mL}$ (Sigma, USA): 1-glucose, 2 - fructose; 3 - sucrose; 4 - raffinose, 5 - melezitose, 6 - inulin. Hydrolysates: 7, 13 - inulin, 11 - raffinose, 12 - melezitose; $60^{\circ} \mathrm{C}, 20$ minutes, $\mathrm{pH} 7.0$, enzyme activity 1.0 $\mathrm{U} / \mathrm{mL}$

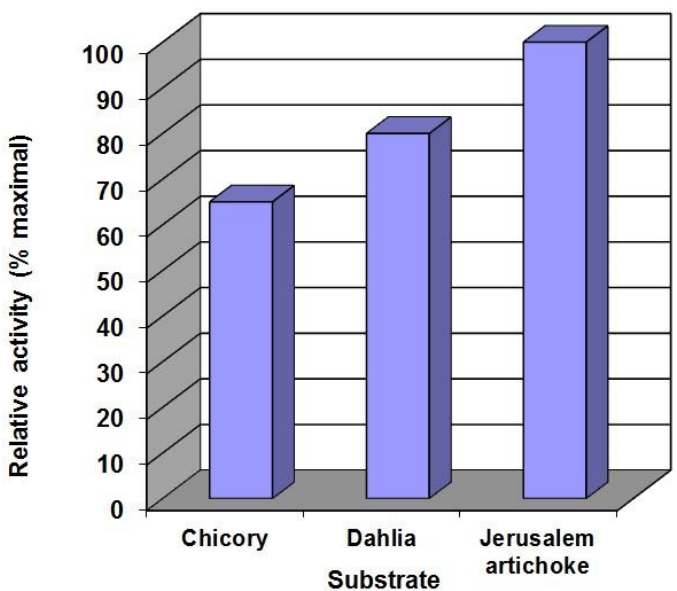

Figure 7 Action of the inulinase on several substrates, enzyme activity $4.0 \mathrm{U} / \mathrm{mL}$.

\section{CONCLUSION}

The application of inulinases to obtain fructose syrups could resolve two main issues in the industry: inulin has a limited solubility at room temperature and microbial contamination is highly probable at this temperature. To avoid contamination the industrial process happens at $60^{\circ} \mathrm{C}$. Most known inulinases lose their activity after a few hours at said temperature and the addition of more enzyme increases the cost of the final product.

Amongst the yeasts, producing inulinases are Kluyveromyces spp., Pichia spp and Candida spp., which could potentially synthesize large quantities of the enzyme (Neagu (Bonciu) and Bahrim, 2011). These inulinases have a $\mathrm{pH}$ optimum of $4.5-5.5$ and a temperature optimum of $40-55^{\circ} \mathrm{C}$. The molecular weight of the enzymes is approximately $60 \mathrm{kDa}$. Although the enzymes produced by Kluyveromyces strains are stable at $50^{\circ} \mathrm{C}$, incubation at $55^{\circ} \mathrm{C}$ and $60^{\circ} \mathrm{C}$ leads to rapid loss of activity, which explains their limited industrial application (Singh and Gill, 2006)

Various fungi have also been reported to synthesize inulinases, which have a $\mathrm{pH}$ optimum between 5.5 and 6.5 and a temperature optimum of $35-45^{\circ} \mathrm{C}$ Thermophillic fungi could produce inulinases with a higher temperature optimum. The molecular weight of these enzymes ranges between $50 \mathrm{kDa}$ and $300 \mathrm{kDa}$.

The exo-inulinase from strain Bacillus sp. SG7 was purified to homogeneity with specific inulinase activity of $18.47 \mathrm{U} / \mathrm{mg}$ protein and specific invertase activity of 196.5 U/mg protein. The purification fold was 10.44 and the yield $27.4 \%$.

The molecular mass of the purified enzyme from strain Bacillus sp. SG7 was determined based on the SDS-PAGE electrophoresis results and was calculated to be $56000 \mathrm{Da}$. $\mathrm{Al}^{3+}, \mathrm{Mn}^{2+}, \mathrm{Fe}^{3+}, \mathrm{Co}^{2+}, \mathrm{Ag}^{+}$inhibit the enzyme activity at the studied ion concentrations. The inhibition ranges between $15 \%$ and $30 \%$. $\mathrm{Fe}^{2+}$ and EDTA affect the enzyme more strongly and inhibit its activity, beginning at $35 \%$ up to $50 \%$. Potent inhibitors are also $\mathrm{Pb}^{2+}, \mathrm{Zn}^{2+}, \mathrm{Hg}^{2+}, \mathrm{Cu}^{2+}$, with inhibition 
reaching $55 \%$ for $\mathrm{Cu}^{2+}$ and $95 \%$ for $\mathrm{Pb}^{2+}$. SDS completely inhibits the purified inulinase. $\mathrm{Km}$ and $\mathrm{Vmax}$ for an inulin substrate are $1.0 \mathrm{mg} / \mathrm{mL}(\mathrm{Km})$ and 6.25 $\mathrm{mg} / \mathrm{mL}$.h (Vmax). The $\mathrm{pH}$-optimum is at $\mathrm{pH} 7.0$ and the enzyme is stable at $\mathrm{pH}$ interval from $\mathrm{pH} 6.0$ to 7.5 , whilst retaining $100 \%$ of its initial activity at $\mathrm{pH}$ interval 6.5-7.0, which distinguishes it from the partially purified enzyme and its $\mathrm{pH}$-stability range from $\mathrm{pH} 5.5$ to 8.0 (Gavrailov and Ivanova, 2014). The temperature optimum of the purified inulinase from strain Bacillus sp. SG7 is $60^{\circ} \mathrm{C}$, which is the same as the temperature optimum of the enzyme in the concentrate. In the presence of inulin, the purified inulinase retains $100 \%$ of its activity for 55 minutes at $65^{\circ} \mathrm{C}$. After the $70^{\text {th }}$ minute the activity decreases to $65 \%$.

In conclusion, enzyme produced by Bacillus sp. SG7 is exo-inulinase according to the presented data about: i) reaction products of inulin hydrolysis (fructose); ii) substrate spectrum (inulin, sucrose, raffinose); iii) and the S/I ratio (10.64). This exo-inulinase could be applied at high temperatures $\left(60-65^{\circ} \mathrm{C}\right)$ and $\mathrm{pH}$ ranges 5.5-7.5 in contrast to the industrial preparations from yeasts and from Aspergillus fungi.

The production of inulinases from thermophiles is characterised by: brief fermentation, due to the rapid growth of thermophiles; low viscosity of the growth medium at high temperatures, which makes aeration and mass exchange easier; reduced risk of microbial contamination; higher substrate solubility; thermostability of the enzyme molecule; suitability for use in the food industry, determined by the thermophiles and their products' nonpathogenic nature.

Acknowledgements: This work was financed by National Science Fund of Bulgaria (Grant DN06/11 from 17.12.2016). The authors declare that no conflict of interest exists.

\section{REFERENCES}

Allais, J.J., Kammoun, S., Blanc, Ph., Girard, Ch., Baratti, J.C. (1986). Isolation and characterization of bacterial strains with inulinase activity. Applied and Environmental Microbiology, 52(5), 1086-1090.

Allais, J.J., Hoyos-Lopez, G., Baratti, J.C. (1987a). Characterization and properties of an inulinase from a thermophilic bacteria. Carbohydrate Polymers, 7, 277-290.

Allais, J.J., Hoyos-Lopez, G., Kammoun, S., Baratti, J.C. (1987b). Isolation and characterization of thermophilic bacterial strains with inulinase activity. Applied and Environmental Microbiology, 53, 942-945

Belamri, M., Sassi, A.H., Savart, M., Tantaoui-Elaraki, A., Cottin, P. (1994) Purification and properties of an extra cellular inulinase-like $\beta$-fructosidase from Bacillus stearothermophilus. Letters in Applied Microbiology, 19(6), 410-413.

https://doi.org/10.1111/j.1472-765X.1994.tb00969.x

Bradford, M.M. (1976). A rapid and sensitive method for the quantification of microgram quantities of protein utilizing the principale of protein-dye binding Analytical Biochemistry, 27, 248-254. https://doi.org/10.1016/00032697(76)90527-3

Blum, H., Beier, H., Gross, H.J. (1987). Improved silver staining of plant proteins, RNA and DNA in polyacrylamide gels. Electrophoresis, 8, 93-99. https://doi.org/10.1002/elps.1150080203

Chi, Z., Zhang, T., Liu, G., Xue, L. (2009). Inulinase-expressing microorganisms and applications of inulinases. Applied Microbiology and Biotechnology, 82, 211-220. https://doi.org/10.1007/s00253-008-1827-1

Chi, Z.M., Zhang, T., Cao, T.S., Liu, X.Y., Cui, W., Zhao, C.H. (2011) Biotechnological potential of inulin for bioprocesses. Bioresource Technology, 102, 4295-4303. http://doi.org/10.1016/j.biortech.2010.12.086

Dixon, M., Webb, E. (1979). In: Dixon, M., Webb, E. (Eds.) Enzymes, $3^{\text {rd }}$ editin, Longman, USA.

Drent, W.J., Lahpor, G.A., Weigant, W.M., Gottschal, J.C. (1991). Fermentation of inulin by Clostridium thermosuccinogenes sp. nov., a thermophilic anaerobic bacterium isolated from various habitats. Applied and Environmental Microbiology, 57(2), 455-462.

Elyachioui, M., Hornez, J.P., Tailliez, R. (1992). General properties of extracellular bacterial inulinase. Journal of Applied Microbiology, 73(6), 514 519. https://doi.org/10.1111/j.1365-2672.1992.tb05014.x

Ettalibi, M., Baratti, J.C. (1987). Purification, properties and comparison of invertase, exoinulinases and endoinulinases of Aspergillus ficuum. Applied Microbiology and Biotechnology, 26, 13-20. https://doi.org/10.1007/BF00282143

Ettalibi, M., Baratti, J.C. (2001). Sucrose hydrolysis by thermostabe immobilized inulinases form Aspergillus ficuum. Enzyme and Microbial Technology, 28, 596 - 601. https://doi.org/10.1016/S0141-0229(00)00342-2

Gao, W., Bao, Y., Liu, Y., Zhang, X., Wang, J., An, L. (2009). Characterization of thermostable endoinulinase from a new strain Bacillus smithii T7. Applied Biochemistry and Biotechnology, 157, 498-506.

https://doi.org/10.1007/s12010-008-8313-1

Gao, J., Xu, Y.Y., Yang, H.M., Xu, H., Xue, F., Li, S., Feng, X.H. (2014). Gene cloning, expression, and characterization of an exo-inulinase from Paenibacillus polymyxa ZJ-9. Applied Biochemistry and Biotechnology, 173, 1419-1430. https://doi.org/10.1007/s12010-014-0950-y
Gavrailov, S., Ivanova, V. (2014). Isolation and characteristics of a thermophilic Bacillus strain, producer of inulinase. Journal of BioScience and Biotechnology, SE/ONLINE, 83-94.

Gill, P.K., Manhas, R.K., Singh, P. (2006). Purification and properties of a heatstable exoinulinase isoform from Aspergillus fumigatus. Bioresource Technology, 97, 894-902. https://doi.org/10.1016/j.biortech.2005.04.034

Gong, F., Zhang, T., Chi, Z., Sheng, J., Li. J., Wang, X. (2008). Purification and characterization of extracellular inulinase from a marine yeast Pichia guilliermondii and inulin hydrolysis by the purified inulinase. Biotechnology and Bioprocess Engineering, 13, 533-539.

https://doi.org/10.1007/s12257-007-0177-7

Guimaraes, L.H.S., Terenzi, H.F., Polizeli, M.L., Jorge, J.A. (2007). Production and characterization of a thermostable extracellular $\beta$-Dfructofuranosidase produced by Aspergillus ochraceus with agroindustrial residues as carbon sources. Enzyme and Microbial Technology, 42, 52-57. https://doi.org/10.1016/j.enzmictec.2007.07.021

Gupta, A.K., Kaur, N. (1997). Fructan storing plants - a potential source of high fructose syrups. Journal of Scientific and Industrial Research, 56(8), 447-452. Ivanova, V.N., Dobreva, E.P., Emanuilova, E.I. (1993). Purification and properties of thermostable alpha-amylase from B. licheniformis 44MB82-A. Journal of Biotechnology, 28, 277-289. http://dx.doi.org/10.1016/0168 1656(93)90176-N

Jain, S.C., Jain, P.C., Kango, N. (2012). Production of inulinase from Kluyveromyces marxianus using dahlia tuber extract. Brazilian Journal of Microbiology, 62-69, ISSN 1517-8382. http://dx.doi.org/10.1590/S1517$\underline{83822012000100007}$

Jenny, S.A., Kavitha, C., Vidyadharan, G., Priya, R., Dhandapani, R. (2012). Isolation of inulinase producing bacteria from sugarcane soil. International Journal of Applied Biology and Pharmaceutical Technology, 3(4), 320-326.

Kango, N., Jain, S.C. (2011). Production and properties of microbial inulinases: recent advances. Food Biotechnology, 25, 165-212. http://dx.doi.org/10.1080/08905436.2011.590763

Kato, K., Araki, T., Kitamura, T., Morita, N., Moori, M., Suzuki, Y. (1999) Purification and properties of a thermostable inulinase ( $\beta$-D-fructan fructohydrolase) from Bacillus stearothermophilus KP1289. Starch, 51, 253-258. https://doi.org/10.1002/(SICI)1521-379X(199907)51:7<253::AID-

STAR253>3.0.CO;2-7

Kim, K.Y., Koo, B.S., Jo, D., Kim, S.I. (2004). Cloning, expression, and purification of exoinulinase from Bacillus sp. snu-7. Journal of Microbiology and Biotechnology, 14, 344-349.

Kobayashi, T., Uchimura, K., Deguchi, S., Horikoshi, K. (2012). Cloning and sequencing of inulinase and $\beta$-fructofuranosidase genes of a deep-sea microbulbifirespecies and properties of recombinant enzymes. Applied and Environmental Microbiology, 78, 2493-2495. PMID:22286980 http://dx.doi.org/10.1128/aem.07442-11

Kochhar, A., Kaur, N., Gupta, A.K. (1997). Inulinase from Aspergillus versicolor. A potent enzyme for producing fructose from inulin, Journal of Scientific and Industrial Research, 56, 721-726.

Kwon, J.M., Kim, H.Y., Choi, Y.J. (2000). Cloning and characterization of Pseudomonas mucidolens exoinulinase. Journal of Microbiology and Biotechnology, 10, 238-243.

Kwon, H.J., Jeon, S.J., You, D.J., Kim, K.H., Jeong, Y.K., Kim, Y.H., Kim,

Y.M., Kim, B.W. 2003. Cloning and characterization of an exoinulinase from Bacillus polymyxa. Biotechnology Letters, 25, 155-159. https://doi.org/10.1023/A:1021987923630

Laemmli, U.K. (1970). Cleavage of structural proteins during the assembly of the head of bacteriophage T4. Nature, 227, 680-685. http://dx.doi.org/10.1038/227680a0

Liebl, W., Brem, D., Gotschlich, A. (1998). Analysis of the gene for $\beta$ fructosidase (invertase, inulinase) of the hyperthermophilic bacterium Thermotoga maritima and characterization of the enzyme expressed in Escherichia coli. Applied Microbiology and Biotechnology, 50, 55-64. https://doi.org/10.1007/s002530051256

Liu, G.L., Fu, G.Y., Chi, Z., Chi, Z.M. (2014). Enhanced expression of the codon-optimized exo-inulinase gene from the yeast Meyerozyma guillermondii in Saccharomyces sp.W0 and bioethanol production from inulin. Applied Microbiology and Biotechnology, 98, 9129-9138.

https://doi.org/10.1007/s00253-014-6079-7

Ma, J-Y., Cao, H-L., Tan, H-D., Nu, X-J., Liu, W-J., Du, Y-G., Yin, H. (2016) Cloning, expression, characterization and mutagenesis of a thermostable exoinulinase from Kluyveromyces cicerisporus. Applied Biochemistry and Biotechnology, 178, 144-158. https://doi.org/10.1007/s12010-015-1864-Z

Martirosyan, G.V. (2004). Inulinase of Bacillus subtilis: extraction, purification and characterization. Electronic Journal of Natural Sciences, 2(1), 38-42.

Meenakshi, S., Umayaparvathi, S., Manivasagan, P., Arumungam, M. Balasubramanian, T. (2013). Purification and characterization of inulinase from marine bacterium, Bacillus cereus MU - 31. Indian Journal of Geo-Marine Sciences, 42(4), $510-515$. 
Miller, G.L. (1959). Use of dinitrosalicylic acid reagent for determination of reducing sugar. Analytical Chemistry, 3, 1426-428. https://doi.org/10.1021/ac60147a030

Moriyama, S., Akimoto, H., Suetsugu, N., Kawasaki, S., Nakamura, T., Ohta. K. (2002). Purification and properties of an extracellular exoinulinase from Penicillium sp. strain TN-88 and sequence analysis of the encoding gene. Bioscience, Biotechnology and Biochemistry, 66, 1887-1896. https://doi.org/10.1271/bbb.66.1887

Nagem, R.A.P., Rojas, A.L., Golubev, A.M., Korneeva, O.S., Eneyskaya, E.V., Kulminskaya, K.N., Neustroev, K.N., Polikarpov, I. (2004). Crystal structure of exo-inulinase from Aspergillus awamori: the enzyme fold and structura determinants of substrate recognition, Journal of Molecular Biology, 344, 471480. https://doi.org/10.1016/j.jmb.2004.09.024

Neagu (Bonciu), C., Bahrim, G. (2011). Inulinases - a versatile tool for biotechnology. Innovative Romanian Food Biotechnology, 9, 1-11.

Pandey, A., Soccol, C.R., Selvakumar, P., Soccol, V.T., Krieger, N., Fontana J.D. (1999). Recent developments in microbial inulinases, its production, properties, and industrial applications. Applied Biochemistry and Biotechnology, 81, 35-52. https://doi.org/10.1385/ABAB:81:1:35

Rocha, J.R., Catana, R., Ferreira, B.S., Cabral, J.M.S., Fernandes, P. (2006) Design and characterisation of an enzyme system for inulin hydrolysis. Food Chemistry, 95: 77-82.

Sharma, A.D., Gill, P.K. (2007). Purification and characterization of heat-stable exo-inulinase from Streptomyces sp. Journal of Food Engineering, 79, 1172 1178. https://doi.org/10.1016/j.jfoodeng.2006.04.008

Shen, J., Zhang, R., Li, J., Tang, X., Li, R., Wang, M., Huang, Z., Zhou, J. (2015). Characterization of an exo-inulinase from Arthrobacter: A novel NaCltolerant exo-inulinase with high molecular mass. Bioengineered, 6(2), 99-105. https://doi.org/10.1080/21655979.2015.1019686

Sheng, J., Chi, Z., Gong, F., Li, J. (2008). Purification and characterization of extracellular inulinase from a marine yeast Cryptococcus aureus G7a and inulin hydrolysis by the purified inulinase. Applied Biochemistry and Biotechnology, 144, 111-121. https://doi.org/10.1007/s12010-007-8025-y

Singh, P., Gill, P.K. (2006). Production of Inulinases. Food Technology and Biotechnology, $44 \quad$ (2), 151-162. https://doi.org/10.1.1.918.708\&rep=rep1\&type=pdf

Singh, R.S., Bhermi, H. (2008). Production of extracellular exoinulinase from Kluyveromyces marxianus YS-1 using root tubers of Asparagus officinalis. Bioresource Technology, 99(15), 7418-7423.

Singh, R.S., Singh, R.P., Yadav, M. (2013). Molecular and biochemical characterization of a new endoinulinase producing bacterial strain of Bacillus safensis AS-08. Biologia, 68(6), 1028-1033. https://doi.org/10.2478/s11756013-0259-2

Sneath, P.H.A. (1986). In: Sneath, P.H.A., Mair, N.S., Sharpe, H.S. (Eds.) Bergey's Mannual of Systematic Bacteriology, Baltimore MD, USA: Williams \& Wilkins, ISBN: 0-683-07893-3, pp. 1104-1141.

Takahashi, N., Mizuno, F., Takamori, K. (1985). Purification and preliminary characterization of exo-beta-D-fructosidase in Streptococcus salivarius KTA-19. Infection and Immunity, 47, 271- 276.

Trivedi, S., Divecha, J., Shah, T., Shah, A. (2015). Rapid and efficient bioconversion of chicory inulin to fructose by immobilized thermostable inulinase from Aspergillus tubingensis CR16. Bioresources and Bioprocessing, 2, 32-42. https://doi.org/10.1186/s40643-015-0060-x

Tsujimoto, Y., Watanabe, A., Nakano, K., Watanabe, K., Matsui, H., Tsuji, K., Tsukihara, T., Suzuki, Y. (2003). Gene cloning, expression, and crystallization of a thermostable exo-inulinase from Geobacillus stearothermophilus KP1289. Applied Microbiology and Biotechnology, 62, 180-185. https://doi.org/10.1007/s00253-003-1261-3

Uzunova, K., Vassileva, A., Ivanova, V., Spasova, D., Tonkova, A. (2002) Thermostable exo-inulinase production by semicontinuous cultivation of membrane-immobilized Bacillus sp. 11 cells. Process Biochemistry, 37(8), 863868. https://doi.org/10.1016/S0032-9592(01)00283-7

Vandamme, E.J., Derycke, D.G. (1983). Microbial inulinases: fermentation process, properties, and applications. Advances in Applied Microbiology, 29, 139 176. https://doi.org/10.1016/S0065-2164(08)70356-3

Vijayaraghavan, K., Yamini, D., Ambika, V., Sowdamini, N.S. (2009). Trends in inulinase production-a review. Critical Reviews in Biotechnology, 29, 67-77. https://doi.org/10.1080/07388550802685389

Vullo, D.L., Coto, C.E., Sineriz, F. (1991). Characteristics of an Inulinase Produced by Bacillus subtilis 430A, a Strain Isolated from the Rhizosphere of Vernonia herbacea (Vell Rusby). Applied and Environmental Microbiology, 57(8), 2392-2394.

Wang, L., Huang, Y., Long, X., Meng, X., Liu, Z. (2011). Cloning of exoinulinase gene from Penicillium janthinellum strain B01 and its high level expression in Pichia pastoris. Applied Microbiology, 111, 1371-1380. https://doi.org/10.1111/j.1365-2672.2011.05145.x

Wanker, E., Huber, A., Schwab, H. (1995). Purification and characterization of the Bacillus subtilis levanase produced in Escherichia coli. Applied and Environmental Microbiology, 61(5), 1953-1958.
Zherebtsov, N.A., Shelamova, S.A., Abramova, I.N. (2002). Biosynthesis of inulinases by Bacillus bacteria. Applied Biochemistry and Microbiology, 38(6), 634-638. https://doi.org/10.1023/A:1020722510374

Zhou, J.P., Lu, Q., Peng, M.Z., Zhang, R., Mo, M.H., Tang, X.H., Li, J.J., Xu, B., Ding, J.M., Huang, Z.X. (2015). Cold-active and NaCl-tolerant exo-inulinase from a cold-adapted Arthrobacter sp. MN8 and its potential for use in the production of fructose at low temperatures. Journal of Biosciences and Bioengineering, 119, 267-274. https://doi.org/10.1016/j.jbiosc.2014.08.003 